\title{
Dissecting the mechanisms and molecules underlying the potential carcinogenicity of red and processed meat in colorectal cancer (CRC): an overview on the current state of knowledge
}

\author{
Marco Cascella ${ }^{1+}$, Sabrina Bimonte ${ }^{1 *+} \mathbb{B}$, Antonio Barbieri ${ }^{2+}, V^{2}$ itale Del Vecchio ${ }^{2 \dagger}$, Domenico Caliendo ${ }^{1}$, \\ Vincenzo Schiavone ${ }^{3}$, Roberta Fusco ${ }^{4}$, Vincenza Granata ${ }^{4}$, Claudio Arra ${ }^{2+}$ and Arturo Cuomo ${ }^{1+}$
}

\begin{abstract}
Meat is a crucial nutrient for human health since it represents a giant supply of proteins, minerals, and vitamins. On the opposite hand, the intake of red and processed meat is taken into account dangerous due to its potential of carcinogenesis and cancer risk improvement, particularly for colorectal cancer (CRC), although it has been reported that also the contaminations of beef infected by oncogenic bovine viruses could increase colorectal cancer's risk. Regarding the mechanisms underlying the potential carcinogenicity of red and processed meat, different hypotheses have been proposed. A suggested mechanism describes the potential role of the heterocyclic amines (HACs) and polycyclic aromatic hydrocarbons (PHAs) in carcinogenesis induced by DNA mutation. Another hypothesis states that heme, through the lipid peroxidation process and therefore the formation of N-nitroso compounds (NOCs), produces cytotoxic and genotoxic aldehydes, resulting in carcinogenesis. Furthermore, a recent proposed hypothesis, is based on the combined actions between the N-Glycolylneuraminic acid (Neu5Gc) and genotoxic compounds. The purpose of this narrative review is to shed a light on the mechanisms underlying the potential carcinogenicity of red and processed meat, by summarizing the data reported in literature on this topic.
\end{abstract}

Keywords: Carcinogenesis, Red meat, Processed meat, Heme, Heterocyclic amines, Polycyclic aromatic hydrocarbons, Neu5Gc

\section{Background}

Meat is an important nutrient for human health, since it represents a big source of proteins, minerals and vitamins with poor bioavailability. Red and processed meats, instead, are considered dangerous, due to their potential carcinogenicity. Red meat is a form of unprocessed mammalians muscle, which color is due to the presence of myoglobin $[1,2]$. On the other facet, processed meat is identified as a product

\footnotetext{
* Correspondence: s.bimonte@istitutotumori.na.it

Claudio Arra and Arturo Cuomo are co-last authors.

Marco Cascella, Sabrina Bimonte, Antonio Barbieri, Vitale Del Vecchio

contributed equally to this work.

${ }^{\dagger}$ Equal contributors

'Division of Anesthesia and Pain Medicine, Istituto Nazionale Tumori - IRCCS

- "Fondazione G. Pascale", Via Mariano Semmola, 80131 Naples, Italy

Full list of author information is available at the end of the article
}

obtained through several processes such as salting, curing, fermentation or smoking, with the aim of enhancing flavor or improve preservation. Recently, the International Agency for Research on Cancer (IARC) published interesting results on the potential carcinogenicity effects of red and/or processed meat; Bouvard et al. [3] anticipated these data and showed that the processed meat is classified as carcinogenic to human (Group 1), while the red meat is identified as probably carcinogenic to human (Group 2A) (Fig. 1). On the basis of this classification, and from knowledge emerged by epidemiological studies, the intake of meat as a nutrient of a healthy diet for human, has to become a controversial issue [4]. Accumulating studies showed that the consumption of processed meat causes colorectal cancer (CRC), the second most common cause of cancer-related death in affluent 


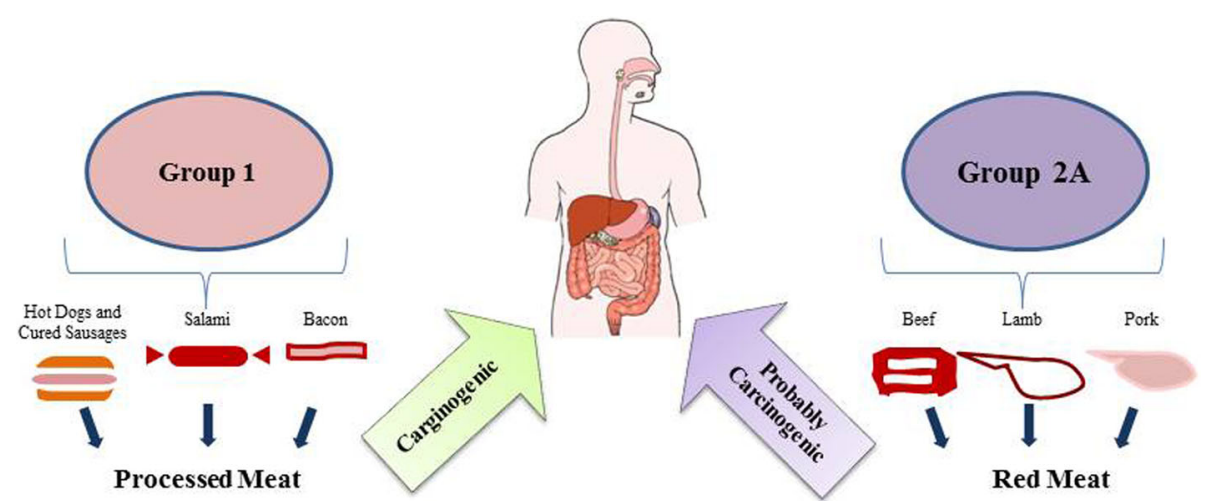

Fig. 1 IARC's classification of red and processed meat. Processed meat has been classified as carcinogenic to human (Group 1), while red meat has been classified as probably carcinogenic to human (Group 2A)

countries, and stomach cancer, although the evidences for this latter are still not enthusiastic. Chan et al. [5] proved evidence that dietary factors, as well as red and processed meat, may be thought of the leading causes of $80 \%$ CRC cases. Similar results, obtained by epidemiological studies accumulated over the last decades, confirmed the association of red and processed meat intake and increased risk of CRC [6-9]. Interestingly, $Z u$ Hausen et al., suggested that potentially oncogenic thermoresistant bovine viruses, by inducing beef's contaminations provoked infections in the colorectal tract, that combined to chemical carcinogens developed during procedures of cooking, increased the colorectal cancer's risk [10]. The role of red meat consumption as a leading cause of different types of cancer (e.g. pancreatic cancer, prostate cancer, bladder cancer) has been conjointly reported [11-16], although extremely mentioned and contested by the scientific community, since a recent meta-analysis indicated a significantly increased risk (about 22\%) of bladder cancer as a result of high processed meat (but not for red meat) consumption [17]. Additionally, in another meta-analysis, Bylsma and Alexander concluded that there was no association between red or processed meat intake and prostate cancer, although they found a weak positive summary estimate for processed meats [18]. A detailed summary of recent epidemiological studies on carcinogenicity of consumption of red and processed meat in different types of cancer, including colorectal cancer (CRC), has been recently reported by Domingo et al. [19] whereas Alexander et al. published a quantitative update on the epidemiological research on the topic [20]. Several molecules have been identified as potential carcinogenic present in red meat or produced by meat processing or by cooking procedure: i) the heterocyclic amines (HACs), as -Amino-3,4- dimethylimidazo quinolone (MeIQ) and 2-Amino-3,8-dimethylimidazo quinoxaline (MeIQx), ii) the $\mathrm{N}$-nitroso-compounds (NOCs), as $\mathrm{N}$ nitrosodimethylamine (NDMA); iii) the polycyclic aromatic hydrocarbons (PAHs), as benzo[a]pyrene (BaP) [17, 21]; iv) the N-glycolylneuraminic acid (Neu5Gc) [22]. In addition, the carcinogenic role of environmental pollutants (e.g., polychlorinated dibenzo-pdioxins and dibenzofurans, polychlorinated biphenyls, polybrominated diphenyl and polychl orinated diphenyl ethers, polychlorinated naphthalene and perfluoroalkyl substances), which are already present in raw or unprocessed meat, has been also proposed [19]. Furthermore, the carcinogenic role of red and processed meat could be enhanced by other concomitant dietary factors (e.g., high fat and/ or protein intake) and clinical conditions, such as obesity [23, 24]. It is of note that bile acids produced in the gut as a consequence of high fat intake, by damaging the mucosa and the epithelium of colon, leads to cell hyperproliferation and then to colon cancer development [25]. Despite studies on animal models supporting the cancerpromoting effect induced by high fat intake [26], epidemiological studies reported opposite results [27, 28]. Similarly, a high protein intake provokes the formations of metabolites toxic with a great potential of colon carcinogenesis [29], although no data supporting this hypothesis, are available [30]. Others alternative and uncertain hypothesis of mechanisms (e.g., thermoresistant potentially oncogenic bovine viruses [10] and endogenous hormones, [31]) underlying the consumption of red and processed meat and carcinogenesis of $\mathrm{CRC}$, have been reported in the literature and reviewed by Demeyer et al. [32]. Our aim is to review the data reported in the literature on the principal mechanisms and molecules involved in carcinogenicity induced by red and processed red meat consumption in CRC, in order to shed a light on the current state of the art on this important issue.

\section{Mechanisms and molecules involved in the carcinogenicity induced by consumption of red and processed meat}

The biological reasons for the association between red and processed meat and cancer- especially CRC- are still unclear, but a large number of molecular mechanisms have been proposed to explain this association. Here, we 
summarize the most relevant ones, trying to elucidate the current state of scientific knowledge.

\section{Heterocyclic amines (HCAs)}

Heterocyclic amines (HCAs) represent chemical compounds generated in fish and meat by cooked procedures at high temperatures through a specific reaction (i.e. Maillard reaction [33]) between free amino acids and sugars, becoming in this way potentially mutagens to humans [34]. It has been reported that the principals HCAs found in cooked red meat (over a total of 25 identified) are the 2-Amino-3, 8-dimethyl imidazo-[4,5f] quinoxaline (MeIQx) and the 2-Amino-1-methyl6 phenylimidazo [4,5b] pyridine (PhIP) [35]. These compounds, together with amino-3,4- dimethylimidazo[4,5-f] quinoline (MeIQ), have been classified by the IARC as potential carcinogenic to human (Group 2B), while the amino-3-methylimidazo[4,5-f] quinolone (IQ) has been classified as probably carcinogenic to human (Group 2A) [3]. It is of note that HCAs are transformed into mutagens after metabolic activation which regulates their carcinogenicity [8]. Evidences support the hypothesis that the levels of these compounds are high in human organisms after the consumption of cooked red beef [36]. Thanks to in vitro and in vivo pre-clinical studies the metabolism and the molecular pathways of MelQx and PhIP's biotransformation have been largely dissected [37-40]. Specifically, the process of hydroxylation of MelQx and PhIP mediated by the cytochrome P-450, has been identified as the principle pathway [41]. Schut et al. [42] showed that HCAs may form DNA adducts. Several epidemiological studies reported a strong association between the HCAs intake and CRC [43-45]. Le Marchand et al. confirmed these data as they reported a strong association between MeIQx and rectal cancer [46]. Unfortunately, opposite results have been described probably due to the higher variability of other factors responsible for carcinogenesis (e.g. diet, genetic polymorphisms of the population) used in epidemiological studies [47, 48]. On the basis of these contrasting results, the link between HCAs and cancer risk is not completely clarified [34]. Thus, more studies will be needed.

\section{The polycyclic aromatic hydrocarbons (PAHs)}

Polycyclic aromatic hydrocarbons (PAHs) are considered toxic substances produced by an incomplete combustion of organic compounds such as tobacco, oil, gas. [49]. Regarding the red meat and other foods, PAHs are produced by cooking procedures at high temperatures, such as barbecuing, or by the food's processing by using smoking [50]. The principal PAH (over 100 identified) classified by the IARC as potential carcinogenic to human (Group 1) is the benzo[a]pyrene (BaP) [3]. Estensen et al., in a pre-clinical study conducted on mice with lung tumors, confirmed the carcinogenic role of $\mathrm{BaP}$ [51]. This molecule becomes genotoxic after metabolic reaction by which is converted into benzo[a]pyrene diolepoxide (BPDE) [52]. This latter is able to interfere with the bases of DNA, thus resulting in DNA damage which is responsible for cancer promoting [53, 54]. Regarding the carcinogenic mechanism of PAHs, Phillips et al., showed that human colon cells are able to metabolize these compounds [50]. Shimada et al. demonstrated that the aryl hydrocarbon receptor, a transcription factor activated by ligands like PAH, plays a crucial role within the regulation and therefore the drug metabolizing enzymes (e.g. CYP1A1, CYP1A2, CYP1B1, glutathione S-transferase and UDP-glucoronyltransferase). These enzymes cause toxicity or carcinogenesis through the processing of the toxicants to reactive metabolites that, finally, interact with cellular macromolecules (e.g., DNA adducts) [55]. Similarly, to HCAs, epidemiological studies do not rumor convincing results on the association between dietary $\mathrm{BaP}$ intake from meat and cancer appearing (mainly CRC), most likely as a result of the difference in un-supporting factors [56, 57] (e.g. cooking procedures, fat contents) chosen in the populations listed in these studies.

Thus, as for HCAs, additional studies are going to be necessary to ascertain the carcinogenicity of red and processed meat induced by PAHs.

\section{Heme}

Heme represents the prosthetic cluster of myoglobin and hemoglobin [28] and is responsible for the red color of meat, as a results of its elevated concentrations respect to those observed in white meat [58]. Due to many epidemiological [59-61] and pre-clinical studies [62, 63], three mechanisms underlying the association between a consumption of heme and CRC risk, have been elucidated: i) the lipid -peroxidation; ii) the $N$-nitroso compounds (NOCs) formations; iii) the cytotoxicity. The potential carcinogenicity of heme iron may be associated to its redox properties. By taking part in dangerous free radical-generating reactions with the production of a reactive oxygen species (ROS), heme iron leads to oxidative DNA damage which is considered highly mutagenic [64]. ROS are involved in lipid peroxidation, a complex process which, finally, causes the formation of cytotoxic and genotoxic aldehydes, as malondialdehyde (MDA) and 4-hydroxynonenal (4-HNE) [65]. These aldehydes are able to promote cancer progression, as reported by epidemiological and experimental studies. Thus, lipid peroxidation as thought of one the principal mechanisms underlying the carcinogenicity of red and processed meat induced by heme (Fig. 2). 


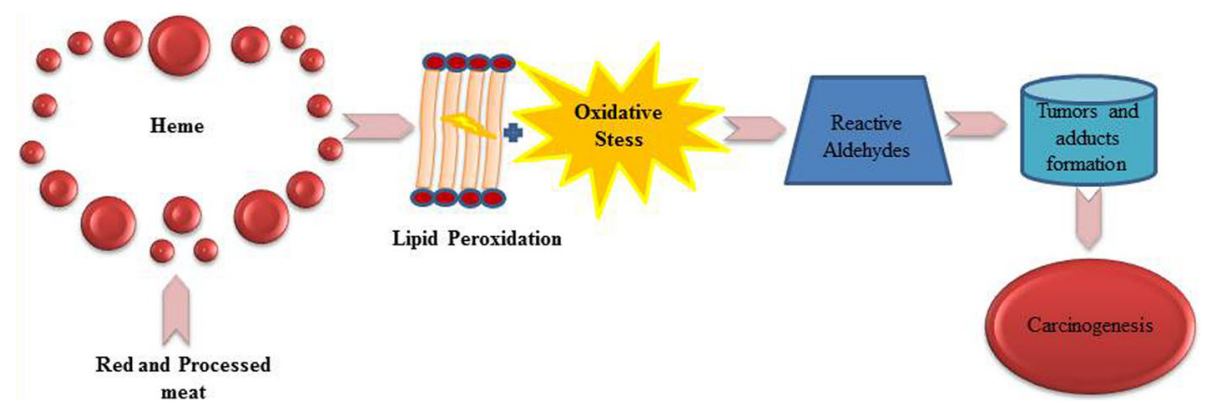

Fig. 2 Lipid peroxidation as a mechanism underlying the carcinogenicity of red and processed meat induced by heme. Heme induces lipid peroxidation trough oxidative stress, resulting in the formations of reactive aldehydes. These cytotoxic aldehydes, cause carcinogenesis by promoting the tumors and therefore the adducts formation

\section{The nitrate/nitrite formation and the N-Nitroso compounds (NOCs)}

Endogenous NOCs, formed by $\mathrm{N}$-nitrosation process of amines and amides, may be considered important genotoxins since being to induce DNA mutations [66]. Most NOCs, as well as nitrosamines, nitrosamides, and nitrosoguanidines [67], can yield alkylating agents (N-alkylNOCs) throughout metabolism. Plenty of nitrosamines are found in foods, including NDMA, NDEA (Nnitrosodiethylamine), NDBA (N-nitrosodibutylamine), NPIP (Nnitrosopiperidine), NPYR (Nnitrosopyrrolidine), NMOR (N-nitrosomorpholine), NDPhA (Nnitrosodiphenylamine), NPRO (Nnitrosoproline), and NSAR (N- nitrososarcosine), although not all of these shows carcinogenic effect [3] (See Fig. 3, for IARC's classification of Nitrosamines). Humans may be exposed to two different forms of NOCs: i) exogenous, derived from different sources (e.g., tobacco products, diet, occupational environments and drugs); ii) endogenous nitrosamines and nitrosamides, generated by the reaction of nitrite with the products of amino acid's degradation in the stomach, and accounted for up 75\% of the total NOC exposure [68]. Several epidemiological and pre-clinical studies conducted on animal models reported a strong link between endogenous NOCs and CRC.

Regarding CRC, studies demonstrated that N-alkyl-NOCs can induce transitions of DNA's bases $(\mathrm{GC} \rightarrow \mathrm{AT})$ in genes mutated (e.g. Kras) in human tumors [69]. Moreover, as shown by Kuhnle et al. [70], the presence of nitrosyl heme, which is formed by a nitrosylation or nitrosation in ileum and in faeces, might promote the formation of extremely reactive alkylating agents like diazoacetate. As a consequence, this process ends up in the formation of the NOC DNA adduct, named O6-carboxymethyl-2'-deoxy-guanosine (O6CMeG). This compound has been wide studied by Lewin et al., as carcinogenetic agent for CRC [71]. DNA damage may be induced by aldehydes with mutagenic effects in microorganism, mammalian, and human cells [72]. For example, Leuratti et al. [73], proved evidence that MDA reacts with DNA to form adducts such as 1, N2- malondialdehyde-deoxyguanosine (M1dG), which has been found at higher levels, in subjects with adenoma compared with adenoma-free subjects. On the other side, the aldehydes 4-hydroxy-2-nonenal (4-HNE) is weakly mutagenic even though is taken into account the most toxic product of lipid peroxidation. In fact, it may interfere with stress apoptosis pathway by causing necrosis in human colon carcinoma cells through the activation of caspase-3 [74]. To overcome the pro-carcinogenic effects of heme, it's been powerfully steered to incorporate in dietary regime a spread of molecules present in fruit and vegetables. As an example, calcium salts and chlorophyll are able to precipitate heme

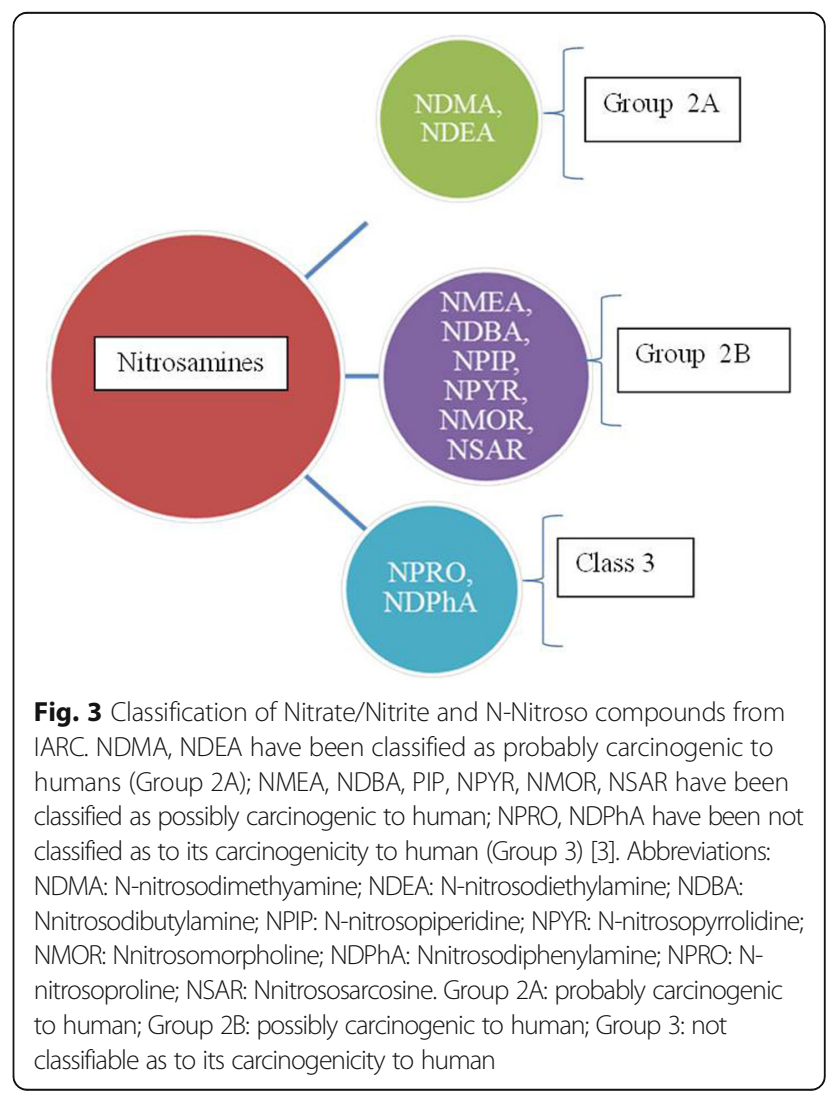


molecules, whereas vitamins $\mathrm{C}$ and $\mathrm{E}$ blocked the endogenous formation of NOCs, and several other polyphenols like quercetin, $\alpha$-tocopherol, or red wine polyphenols, suppressed the lipid peroxidation.

Fewer pre-clinical studies conducted on animal models, showed that heme is able to augment the citoxocity of colon cells, resulting in an increased epithelial proliferation and afterward to cancer occurring [10, 75]. Unfortunately, few epidemiological studies [63, 76] confirmed these knowledges resulting in interpretations that lack of consistency.

\section{$\mathrm{N}$-glycolylneuraminic acid (Neu5Gc)}

Red meat is enriched in glycan's containing a variant of sialic acid, the N-glycolylneuraminic acid (Neu5G). This molecule, not naturally found in human tissues, may be solely assumed by diet regimens containing pork, beef, and lamb [22, 77]. To the current issue, it has been suggested that humans can metabolically incorporate and express Neu5Gc into cell surface glyco-conjugates [78]. Moreover, it has been reported that the incorporation of Neu5Gc into human tissue could be involved in tumor initiation and progression [79]. The mechanism of uptake and incorporation of Neu5Gc into human epithelial was described by Bardor et al., 2005) [80]. It is necessary to underline that Neu5Gc-containing glycans act as "xeno-autoantigens" that may be targeted by naturally circulating anti-Neu5Gc "xeno-autoantibodies". This process ends up in development of xenosialitis, an inflammatory disease that influences cancer formation and progression [81, 82].

Due to the absence of epidemiological data, is suitable to consider the xenosialitis induced by Neu5Gc assumed by red meat consumption, as the only mechanism underlying the association between red meat consumption and increased CRC risk.

\section{Conclusion}

In 2015 the IARC classified the consumption of red meat and processed meat as "probably carcinogenic to humans" (Group 2A), and as "carcinogenic to humans" (Group 1), respectively. A large number of mechanisms have been proposed to elucidate the link between red and processed intake and CRC risk. These mechanisms involve different molecules: i) heme iron, ii) NOCs, iii) HCAs and PAHs; iv) Neu5G, although convincing results have been reported for heme (via lipid peroxidation mechanism) and endogenous NOC. Taking into the account that different compounds could also be present in red and processed red meat, the increased risk for CRC could also be related to multiple carcinogenic compounds (Fig. 4). More studies are going to be necessary

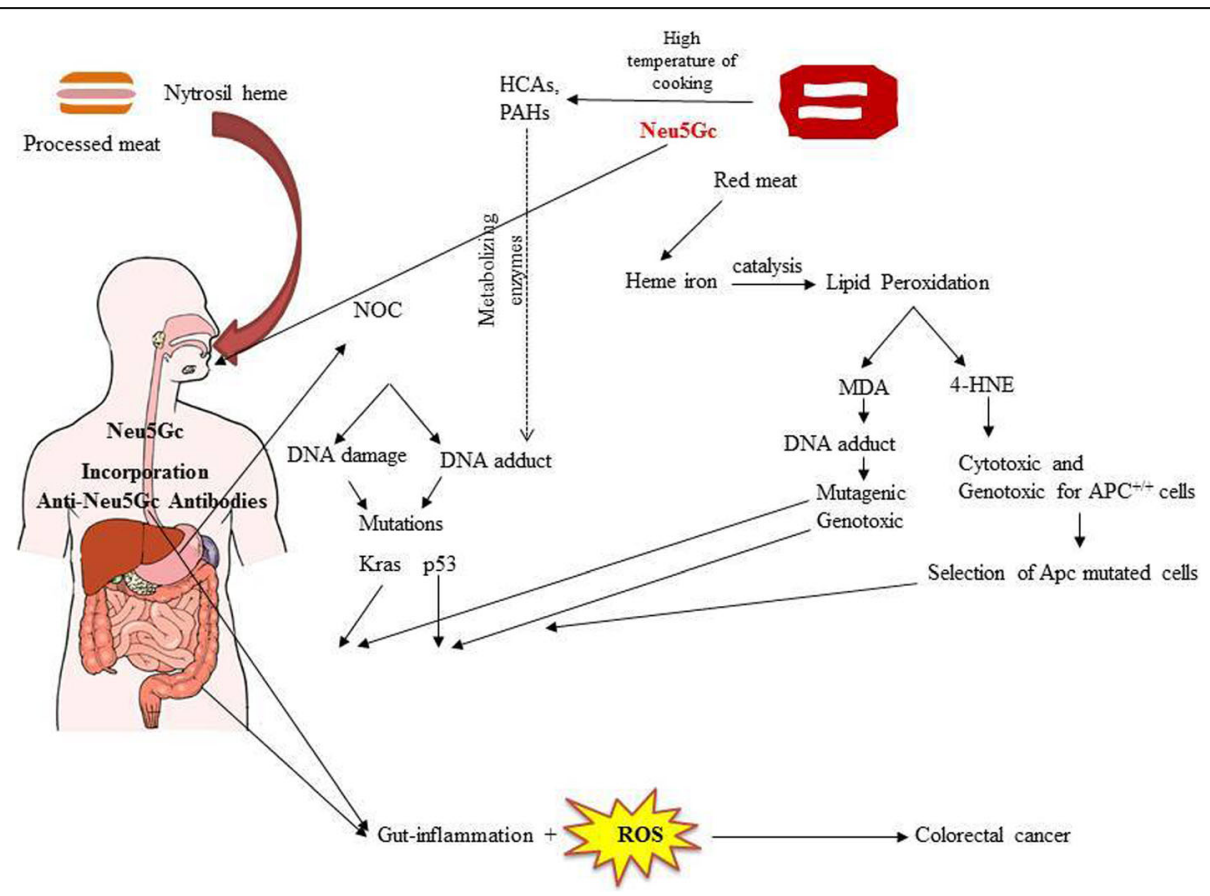

Fig. 4 Mechanisms underlying the carcinogenesis of red and processed meat in CRC. Polycyclic aromatic hydrocarbons (PAHs) and heterocyclic amines (HCAs) produced after cooking procedures at hight temperatures, after metabolic activation, lead to the formation of DNA adduct in epthelial cells with great potential carncinogenesis to CRC. Heme, by lipid peroxidation and endogenous formation of N-nitroso compounds (NOCs), provokes several DNA mutations responsible for CRC. Then, an inflammation process generated by an association of products of lipid peroxidation induced by heme, reactive oxygen species (ROS) present in red and processed meat, and Neu5GS, could enhance the CRC development 
to elucidate the molecular mechanisms underlying the carcinogenicity of red meat and processed meat in CRC and other types of cancer.

\begin{abstract}
Abbreviations
(Neu5Gc): N-Glycolylneuraminic acid; (NOCs): N-nitroso compounds; 4-HNE: 4hydroxy-2-nonenal; Bap: Benzo[a]pyrene; CRC: Colorectal cancer; HCAs: Heterocyclic amines; IQ: Amino-3-methylimidazo[4,5 flquinolone (IQ); M1dg: 1,N2-malondialdehyde-deoxyguanosine; MelQ: amino-3,4dimethylimidazo[4,5-f] quinolone; MelQx: 2-Amino-3,8-dimethylimidazo[4,5f]quinoxaline; NDBA: N-nitrosodibutylamine; NDEA: Nnitrosodiethylamine; NDMA: N-nitrosodimethyamine; NDPhA: N-nitrosodiphenylamine; NMOR: Nnitrosomorpholine; NPIP: N-nitrosopiperidine; NPRO: N-nitrosoproline; NPYR: Nnitrosopyrrolidine; NSAR: N-nitrososarcosine; O6CMeG: O6-carboxymethyl-2'deoxy-guanosine; PHAs: Polycyclic aromatic hydrocarbons; PhIP: 2-Amino-1methyl6 phenylimidazo[4,5b]pyridine; ROS: Reactive oxygen species
\end{abstract}

\section{Acknowledgements}

We are grateful to Dr. Alessandra Trocino, Mrs. MariaCristina Romano and Mr. Massimiliano Spinelli from the National Cancer Institute of Naples for providing excellent bibliographic service and informatics assistance.

\section{Funding}

No funds were used for the preparation of the paper.

\section{Availability of data and materials}

The data and materials are available in the main manuscript.

\section{Authors' contributions}

$M C$, and $S B$, are the main authors of the manuscript. All authors read and approved the final manuscript.

\section{Ethics approval and consent to participate}

Not applicable.

\section{Consent for publication}

Not applicable.

\section{Competing interests}

The authors declare that they have no competing interests.

\section{Publisher's Note}

Springer Nature remains neutral with regard to jurisdictional claims in published maps and institutional affiliations.

\section{Author details}

'Division of Anesthesia and Pain Medicine, Istituto Nazionale Tumori - IRCCS - "Fondazione G. Pascale", Via Mariano Semmola, 80131 Naples, Italy. ${ }^{2}$ S.S.D. Sperimentazione Animale, Istituto Nazionale Tumori - IRCCS - Fondazione "G. Pascale", Via Mariano Semmola, 80131 Naples, Italy. ${ }^{3}$ Division of Anesthesia and Intensive Care, Hospital "Pineta Grande", Castel Volturno, Caserta, Italy. ${ }^{4}$ Division of Radiology, "Istituto Nazionale Tumori - IRCCS - Fondazione G. Pascale", Via Mariano Semmola, 80131 Naples, Italy.

\section{Received: 11 October 2017 Accepted: 2 January 2018}

\section{Published online: 15 January 2018}

\section{References}

1. Lindahl G, Lundstrom K, Tornberg E. Contribution of pigment content, myoglobin forms and internal reflectance to the colour of pork loin and ham from pure breed pigs. Meat Sci. 2001;59:141-51.

2. Sen AR, Muthukumar M, Naveena BM, Ramanna DB. Effects on colour characteristics of buffalo meat during blooming, retail display and using vitamin C during refrigerated storage. J Food Sci Technol. 2014;51:3515-9.

3. Bouvard V, Loomis D, Guyton KZ, Grosse Y, Ghissassi FE, Benbrahim-Tallaa L, Guha N, Mattock H, Straif K. International Agency for Research on Cancer monograph working $\mathrm{G}$ : carcinogenicity of consumption of red and processed meat. Lancet Oncol. 2015;16:1599-600.

4. Celada P. Bastida S, Sanchez-Muniz FJ. To eat or not to eat meat. That is the question. Nutr Hosp. 2016;33:177-81.
5. Chan DS, Lau R, Aune D, Vieira R, Greenwood DC, Kampman E, Norat T. Red and processed meat and colorectal cancer incidence: meta-analysis of prospective studies. PLoS One. 2011;6:e20456.

6. Diallo A, Deschasaux M, Latino-Martel P, Hercberg S, Galan P, Fassier P, Allès $B$, Guéraud F, Pierre FH, Touvier M. Red and processed meat intake and cancer risk: Results from the prospective NutriNet-Santé cohort study. Int J Cancer. 2018;142(2):230-7. https:/doi.org/10.1002/ijc.31046. Epub 2017 Oct 16.

7. Boada LD, Henriquez-Hernandez LA, Luzardo OP. The impact of red and processed meat consumption on cancer and other health outcomes: epidemiological evidences. Food Chem Toxicol. 2016;92:236-44.

8. Cross AJ, Sinha R. Meat-related mutagens/carcinogens in the etiology of colorectal cancer. Environ Mol Mutagen. 2004;44:44-55.

9. Kassier SM. Colon Cancer and the consumption of red and processed meat: an association that ismedium, rare or well done? South African Journal of Clinical Nutrition. 2016;29:145-9.

10. zur Hausen H. Red meat consumption and cancer: reasons to suspect involvement of bovine infectious factors in colorectal cancer. Int J Cancer. 2012;130:2475-83

11. Butler C, Lee Y-CA, Li S, Li Q, Chen C-J, Hsu W-L, Lou P-J, Zhu C, Pan J, Shen $H$, et al. Diet and the risk of head-and-neck cancer among never-smokers and smokers in a Chinese population. Cancer Epidemiology. 2017:46:20-6.

12. Caini S, Masala G, Gnagnarella P, Ermini I, Russell-Edu W, Palli D, Gandini S. Food of animal origin and risk of non-Hodgkin lymphoma and multiple myeloma: a review of the literature and metaanalysis. Crit Rev Oncol Hematol. 2016;100:16-24.

13. Lippi G, Mattiuzzi C, Cervellin G. Meat consumption and cancer risk: a critical review of published meta-analyses. Crit Rev Oncol Hematol. 2016;97:1-14.

14. Grundy A, Poirier AE, Khandwala F, McFadden A, Friedenreich CM, Brenner DR. Cancer incidence attributable to red and processed meat consumption in Alberta in 2012. CMAJ Open. 2016:4:E768-75.

15. Wu K, Spiegelman D, Hou T, Albanes D, Allen NE, Berndt SI, van den Brandt PA, Giles GG, Giovannucci E, Alexandra Goldbohm R, et al. Associations between unprocessed red and processed meat, poultry, seafood and egg intake and the risk of prostate cancer: a pooled analysis of 15 prospective cohort studies. Int J Cancer. 2016;138:2368-82.

16. Wolk A. Potential health hazards of eating red meat. J Intern Med. 2017;281: 106-22.

17. Li F, An S, Hou L, Chen P, Lei C, Tan W. Red and processed meat intake and risk of bladder cancer:a meta-analysis. Int J Clin Exp Med. 2014;7:2100-10.

18. Bylsma $L C$, Alexander DD. A review and meta-analysis of prospective studies of red and processed meat, meat cooking methods, heme iron, heterocyclic amines and prostate cancer. Nutr J. 2015;14:125.

19. Domingo JL, Nadal M. Carcinogenicity of consumption of red meat and processed meat: a review of scientific news since the IARC decision. Food Chem Toxicol. 2017;105:256-61.

20. Alexander DD, Weed DL, Miller PE, Mohamed MA. Red meat and colorectal cancer: a quantitative update on the state of the epidemiologic science. J Am Coll Nutr. 2015;34:521-43.

21. Carr PR, Walter V, Brenner H, Hoffmeister M. Meat subtypes and their association with colorectal cancer: systematic review and meta-analysis. Int Cancer. 2016:138:293-302.

22. Samraj AN, Pearce OM, Laubli H, Crittenden AN, Bergfeld AK, Banda K, Gregg CJ, Bingman AE, Secrest P, Diaz SL, et al. A red meat-derived glycan promotes inflammation and cancer progression. Proc Natl Acad Sci U S A. 2015;112:542-7.

23. Calle EE, Kaaks R. Overweight, obesity and cancer: epidemiological evidence and proposed mechanisms. Nat Rev Cancer. 2004;4:579-91.

24. Jung UJ, Choi MS. Obesity and its metabolic complications: the role of adipokines and the relationship between obesity, inflammation, insulin resistance, dyslipidemia and nonalcoholic fatty liver disease. Int J Mol Sci. 2014;15:6184-223.

25. Bruce WR. Recent hypotheses for the origin of colon cancer. Cancer Res. 1987:47:4237-42.

26. Zhao LP, Kushi LH, Klein RD, Prentice RL. Quantitative review of studies of dietary fat and rat colon carcinoma. Nutr Cancer. 1991;15:169-77.

27. Liu L, Zhuang W, Wang RQ, Mukherjee R, Xiao SM, Chen Z, XT W, Zhou Y, Zhang HY. Is dietary fat associated with the risk of colorectal cancer? A meta-analysis of 13 prospective cohort studies. Eur J Nutr. 2011:50:173-84.

28. Santarelli RL, Pierre F, Corpet DE. Processed meat and colorectal cancer: a review of epidemiologic and experimental evidence. Nutr Cancer. 2008:60:131-44. 
29. Corpet DE, Yin Y, Zhang XM, Remesy C, Stamp D, Medline A, Thompson L, Bruce WR, Archer MC. Colonic protein fermentation and promotion of colon carcinogenesis by thermolyzed casein. Nutr Cancer. 1995;23:271-81.

30. Windey K, De Preter V, Verbeke K. Relevance of protein fermentation to gut health. Mol Nutr Food Res. 2012;56:184-96.

31. Toden S, Belobrajdic DP, Bird AR, Topping DL, Conlon MA. Effects of dietary beef and chicken with and without high amylose maize starch on blood malondialdehyde, interleukins, IGF-I, insulin, leptin, MMP-2, and TIMP-2 concentrations in rats. Nutr Cancer. 2010;62:454-65.

32. Demeyer D, Mertens B, De Smet S, Ulens M. Mechanisms linking colorectal cancer to the consumption of (processed) red meat: a review. Crit Rev Food Sci Nutr. 2016;56:2747-66.

33. Zheng W, Lee SA. Well-done meat intake, heterocyclic amine exposure, and cancer risk. Nutr Cancer. 2009;61:437-46.

34. Alaejos MS, Gonzalez V, Afonso AM. Exposure to heterocyclic aromatic amines from the consumption of cooked red meat and its effect on human cancer risk: a review. Food Addit Contam Part A Chem Anal Control Expo Risk Assess. 2008:25:2-24.

35. Puangsombat K, Gadgil P, Houser TA, Hunt MC, Smith JS. Occurrence of heterocyclic amines in cooked meat products. Meat Sci. 2012;90:739-46.

36. Lynch AM, Knize MG, Boobis AR, Gooderham NJ, Davies DS, Murray S. Intraand interindividual variability in systemic exposure in humans to 2 -amino3,8-dimethylimidazo[4,5-f]quinoxaline and 2-amino-1-methyl- 6phenylimidazo[4,5-b]pyridine, carcinogens present in cooked beef. Cancer Res. 1992;52:6216-23.

37. Yamazoe Y, Abu-Zeid M, Manabe S, Toyama S, Kato R. Metabolic activation of a protein pyrolysate promutagen 2-amino-3,8-dimethylimidazo[4,5flquinoxaline by rat liver microsomes and purified cytochrome P-450. Carcinogenesis. 1988;9:105-9.

38. Wallin $\mathrm{H}$, Holme JA, Becher $\mathrm{G}$, Alexander J. Metabolism of the food carcinogen 2-amino-3,8-dimethylimidazo[4,5-f]quinoxaline in isolated rat liver cells. Carcinogenesis. 1989;10:1277-83.

39. Turteltaub KW, Knize MG, Buonarati MH, McManus ME, Veronese ME, Mazrimas JA, Felton JS. Metabolism of 2-amino-1-methyl-6phenylimidazo[4,5-b] pyridine (PhIP) by liver microsomes and isolated rabbit cytochrome P450 isozymes. Carcinogenesis. 1990;11:941-6.

40. Turesky RJ, Bracco-Hammer I, Markovic J, Richli U, Kappeler AM, Welti DH. The contribution of Noxidation to the metabolism of the food-borne carcinogen 2-amino-3,8-dimethylimidazo[4,5-f]quinoxaline in rat hepatocytes. Chem Res Toxicol. 1990:3:524-35.

41. Hayatsu H, Kasai H, Yokoyama S, Miyazawa T, Yamaizumi Z, Sato S, Nishimura S, Arimoto S, Hayatsu T, Ohara Y. Mutagenic metabolites in urine and feces of rats fed with 2-amino-3,8- dimethylimidazo[4,5-f]quinoxaline, a carcinogenic mutagen present in cooked meat. Cancer Res. 1987:47:791-4.

42. Schut HA, Snyderwine EG. DNA adducts of heterocyclic amine food mutagens: implications for mutagenesis and carcinogenesis. Carcinogenesis. 1999:20:353-68.

43. Helmus DS, Thompson CL, Zelenskiy S, Tucker TC, Li L. Red meat-derived heterocyclic amines increase risk of colon cancer: a population-based casecontrol study. Nutr Cancer. 2013;65:1141-50

44. Kampman E, Slattery ML, Bigler J, Leppert M, Samowitz W, Caan BJ, Potter JD. Meat consumption, genetic susceptibility, and colon cancer risk: a United States multicenter case-control study. Cancer Epidemiol Biomark Prev. 1999:8:15-24

45. Butler LM, Sinha R, Millikan RC, Martin CF, Newman B, Gammon MD, Ammerman AS, Sandler RS. Heterocyclic amines, meat intake, and association with colon cancer in a population-based study. Am J Epidemiol. 2003;157:434-45.

46. Le Marchand L, Hankin JH, Pierce LM, Sinha R, Nerurkar PV, Franke AA, Wilkens $L R$, Kolonel $L N$, Donlon T, Seifried A, et al. Well-done red meat, metabolic phenotypes and colorectal cancer in Hawaii. Mutat Res. 2002;506507:205-14.

47. Nothlings U, Yamamoto JF, Wilkens LR, Murphy SP, Park SY, Henderson BE, Kolonel LN, Le Marchand L. Meat and heterocyclic amine intake, smoking, NAT1 and NAT2 polymorphisms, and colorectal cancer risk in the multiethnic cohort study. Cancer Epidemiol Biomark Prev. 2009;18:2098-106.

48. Tiemersma EW, Voskuil DW, Bunschoten A, Hogendoorn EA, Witteman BJ, Nagengast FM, Glatt H, Kok FJ, Kampman E. Risk of colorectal adenomas in relation to meat consumption, meat preparation, and genetic susceptibility in a Dutch population. Cancer Causes Control. 2004;15:225-36.
49. Mastrangelo G, Fadda E, Marzia V. Polycyclic aromatic hydrocarbons and cancer in man. Environ Health Perspect. 1996;104:1166-70.

50. Phillips DH. Polycyclic aromatic hydrocarbons in the diet. Mutat Res. 1999; 443:139-47.

51. Estensen RD, Jordan MM, Wiedmann TS, Galbraith AR, Steele VE, Wattenberg LW. Effect of chemopreventive agents on separate stages of progression of benzo[alpha]pyrene induced lung tumors in a/J mice. Carcinogenesis. 2004;25:197-201.

52. Yang SK, McCourt DW, Roller PP, Gelboin HV. Enzymatic conversion of benzo(a)pyrene leading predominantly to the diol-epoxide $r-7, t-8$ dihydroxy-t-9,10-oxy-7,8,9,10- tetrahydrobenzo(a)pyrene through a single enantiomer of $r-7, \mathrm{t}-8$-dihydroxy-7,8-dihydrobenzo(a)pyrene. Proc Natl Acad Sci U S A. 1976;73:2594-8.

53. Phillips DH. Fifty years of benzo(a)pyrene. Nature. 1983;303:468-72.

54. Phillips DH, Grover PL. Polycyclic hydrocarbon activation: bay regions and beyond. Drug Metab Rev. 1994;26:443-67.

55. Shimada T. Xenobiotic-metabolizing enzymes involved in activation and detoxification of carcinogenic polycyclic aromatic hydrocarbons. Drug Metab Pharmacokinet. 2006;21:257-76.

56. Tabatabaei SM, Heyworth JS, Knuiman MW, Fritschi L. Dietary benzo[a]pyrene intake from meat and the risk of colorectal cancer. Cancer Epidemiol Biomark Prev. 2010;19:3182-4.

57. Ferrucci LM, Sinha R, Graubard BI, Mayne ST, Ma X, Schatzkin A, Schoenfeld PS, Cash BD, Flood A, Cross AJ. Dietary meat intake in relation to colorectal adenoma in asymptomatic women. Am J Gastroenterol. 2009;104:1231-40.

58. Schwartz S, Ellefson M. Quantitative fecal recovery of ingested hemoglobinheme in blood: comparisons by HemoQuant assay with ingested meat and fish. Gastroenterology. 1985;89:19-26.

59. Bastide NM, Pierre FH, Corpet DE. Heme iron from meat and risk of colorectal cancer: a metaanalysis and a review of the mechanisms involved. Cancer Prev Res (Phila). 2011;4:177-84.

60. Qiao L, Feng Y. Intakes of heme iron and zinc and colorectal cancer incidence: a meta-analysis of prospective studies. Cancer Causes Control. 2013;24:1175-83.

61. Gilsing AM, Fransen F, de Kok TM, Goldbohm AR, Schouten $L$, de Bruine $A P$, van Engeland M, van den Brandt PA, de Goeij AF, Weijenberg MP. Dietary heme iron and the risk of colorectal cancer with specific mutations in KRAS and APC. Carcinogenesis. 2013;34:2757-66.

62. Pierre F, Freeman A, Tache S, Van der Meer R, Corpet DE. Beef meat and blood sausage promote the formation of azoxymethane-induced mucin-depleted foci and aberrant crypt foci in rat colons. J Nutr. 2004:134:2711-6.

63. Sesink AL, Termont DS, Kleibeuker JH, Van der Meer R. Red meat and colon cancer: the cytotoxic and hyperproliferative effects of dietary heme. Cancer Res. 1999:59:5704-9.

64. Fonseca-Nunes A, Jakszyn P, Agudo A. Iron and cancer risk-a systematic review and meta-analysis of the epidemiological evidence. Cancer Epidemiol Biomark Prev. 2014;23:12-31.

65. Betteridge DJ. What is oxidative stress? Metabolism. 2000;49:3-8.

66. Dietrich M, Block G, Pogoda JM, Buffler P, Hecht S, Preston-Martin S. A review: dietary and endogenously formed $\mathrm{N}$-nitroso compounds and risk of childhood brain tumors. Cancer Causes Control. 2005;16:619-35.

67. Lijinsky W. N-Nitroso compounds in the diet. Mutat Res. 1999:443:129-38.

68. Tricker AR. N-nitroso compounds and man: sources of exposure, endogenous formation and occurrence in body fluids. Eur J Cancer Prev. 1997;6:226-68.

69. Bos JL. Ras oncogenes in human cancer: a review. Cancer Res. 1989;49: 4682-9.

70. Kuhnle GG, Story GW, Reda T, Mani AR, Moore KP, Lunn JC, Bingham SA. Diet-induced endogenous formation of nitroso compounds in the GI tract. Free Radic Biol Med. 2007:43:1040-7.

71. Lewin MH, Bailey N, Bandaletova T, Bowman R, Cross AJ, Pollock J, Shuker $D E$, Bingham SA. Red meat enhances the colonic formation of the DNA adduct O6-carboxymethyl guanine: implications for colorectal cancer risk. Cancer Res. 2006;66:1859-65.

72. Niedernhofer LJ, Daniels JS, Rouzer CA, Greene RE, Marnett LJ. Malondialdehyde, a product of lipid peroxidation, is mutagenic in human cells. J Biol Chem. 2003;278:31426-33.

73. Leuratti C, Watson MA, Deag EJ, Welch A, Singh R, Gottschalg E, Marnett $L_{\text {, }}$ Atkin W, Day NE, Shuker DE, Bingham SA. Detection of malondialdehyde DNA adducts in human colorectal mucosa: relationship with diet and the presence of adenomas. Cancer Epidemiol Biomark Prev. 2002;11:267-73. 
74. Awasthi YC, Sharma R, Cheng JZ, Yang Y, Sharma A, Singhal SS, Awasthi S. Role of 4-hydroxynonenal in stress-mediated apoptosis signaling. Mol Asp Med. 2003;24:219-30.

75. ljssennagger N, Rijnierse A, de Wit NJ, Boekschoten MV, Dekker J, Schonewille A, Muller M, van der Meer R. Dietary heme induces acute oxidative stress, but delayed cytotoxicity and compensatory hyperproliferation in mouse colon. Carcinogenesis. 2013;34:1628-35.

76. Pierre F, Peiro G, Tache S, Cross AJ, Bingham SA, Gasc N, Gottardi G, Corpet $D E$, Gueraud F. New marker of colon cancer risk associated with heme intake: 1,4-dihydroxynonane mercapturic acid. Cancer Epidemiol Biomark Prev. 2006;15:2274-9.

77. Chou HH, Takematsu H, Diaz S, Iber J, Nickerson E, Wright KL, Muchmore EA, Nelson DL, Warren ST, Varki A. A mutation in human CMP-sialic acid hydroxylase occurred after the homo-pan divergence. Proc Natl Acad Sci U S A. 1998;95:11751-6.

78. Tangvoranuntakul P, Gagneux P, Diaz S, Bardor M, Varki N, Varki A, Muchmore E. Human uptake and incorporation of an immunogenic nonhuman dietary sialic acid. Proc Natl Acad Sci U S A. 2003;100:12045-50.

79. Samraj AN, Laubli H, Varki N, Varki A. Involvement of a non-human sialic acid in human cancer. Front Oncol. 2014;4:33.

80. Bardor M, Nguyen DH, Diaz S, Varki A. Mechanism of uptake and incorporation of the non-human sialic acid N-glycolylneuraminic acid into human cells. J Biol Chem. 2005;280:4228-37.

81. Padler-Karavani V, Hurtado-Ziola N, Pu M, Yu H, Huang S, Muthana S, Chokhawala HA, Cao H, Secrest P, Friedmann-Morvinski D, et al. Human xenoautoantibodies against a non-human sialic acid serve as novel serum biomarkers and immunotherapeutics in cancer. Cancer Res. 2011;71:3352-63.

82. Padler-Karavani $\mathrm{V}$, Varki A. Potential impact of the non-human sialic acid Nglycolylneuraminic acid on transplant rejection risk. Xenotransplantation. 2011;18:1-5

\section{Submit your next manuscript to BioMed Central and we will help you at every step:}

- We accept pre-submission inquiries

- Our selector tool helps you to find the most relevant journal

- We provide round the clock customer support

- Convenient online submission

- Thorough peer review

- Inclusion in PubMed and all major indexing services

- Maximum visibility for your research

Submit your manuscript at www.biomedcentral.com/submit 